\title{
Trehalase activity in genetically diabetic mice (serum, kidney, and liver)*
}

\author{
F C BAUMANN $\uparrow$, F BOIZARD-CALLAIS $\ddagger$, AND J LABAT-ROBERT $\S$ \\ From $\dagger$ the Laboratoire de Chimie Biologique, and †the Laboratoire d'Hygiène, Faculté des Sciences \\ Pharmaceutiques et Biologiques, 4 Avenue de l'Observatoire, 75006 Paris; and \\ $\S$ the Laboratoire de Biochimie du Tissu Conjonctif, Faculté de Médecine, 8 rue de Général Sarrail, \\ 94010 Créteil, France
}

SUMmARY Trehalase activity was determined in serum, liver, and kidney in alloxan treated Swiss $\dot{\infty}$ mice and in homozygous $(\mathrm{Ob} / \mathrm{Ob}, \mathrm{Db} / \mathrm{Db})$ and heterozygous $(\mathrm{Ob} /+, \mathrm{Db} / \mathrm{m}+)$ diabetic mice.

Both alloxan and genetic diabetic mice exhibited a large increase in serum and liver trehalase $\vec{A}$ activity with no change in kidney trehalase activity. The heterozygotes $(\mathrm{Ob} /+, \mathrm{Db} / \mathrm{m}+) \operatorname{showed}_{\mathrm{O}}^{\infty}$ only a slight increase of enzyme activity.

Further quantitative differences were noticed between the genetic and alloxan diabetic animals. $\vec{\nabla}$ The liver enzyme activity increased from 10 - to more than 20 -fold in the liver of the homozygous $\mathrm{Ob} / \mathrm{Ob}$ and $\mathrm{Db} / \mathrm{Db}$ strains and only 3-fold (not significant compared to controls) in the alloxan $\frac{\mathbb{S}}{3}$ treated animals. The above results suggest a regulatory relationship between the genes coding for trehalase and the enzymes of glucose metabolism activity involved in the development of the metabolic anomalies of diabetes. The structural gene for trehalase may well have survived elimin $\$-\infty$ tion of selective pressure during phylogenesis and remained part of a co-regulated group of glucose:metabolising enzymes. This could explain its sensitivity to mutations affecting glucose metabolis⿳亠丷⿵冂丶 and its sensitivity to insulin directed regulatory mechanisms.

Trehalase (glucoside 1,1 glucohydrolase, EC 3.2.1.28) is widespread in nature. ${ }^{1}$ In mammals, it is present in kidney, liver, small intestine, urine, and bile. Its natural substrate, $\alpha, \alpha$-trehalose, has, however, never been characterised in mammals. All the enzymes necessary for its synthesis are nevertheless present in the renal cortex, ${ }^{2}$ and some years ago Sacktor and Berger $^{3}$ described the synthesis of ${ }^{14} \mathrm{C}$-trehalose by incubating rabbit renal cortex slices with ${ }^{14} \mathrm{C}$-glucose. In spite of these results, the biological role of trehalase in mammals remains unknown. Trehalase present in the brush border membrane of small intestine may be responsible for the hydrolysis of trehalose in the intestinal tract absorbed with food. ${ }^{4}$ Alternatively, trehalase may have no role to play in the organism whatsoever.

Serum trehalase activity has been shown to be fairly constant in the same subject, although large variations have been noticed from one person to another. ${ }^{5}$

An increased serum trehalase activity has been

*Supported by CNRS (Groupe No 40)

Received for publication 30 December 1980 reported in human diabetes mellitus, ${ }^{6}$ without any $\stackrel{\mathbb{Q}}{\rightarrow}$ apparent relationship to serum glucose levels. ${ }^{7} \overrightarrow{\overrightarrow{0}}$ It was tempting therefore to explore the possibility of a relationship between disturbed glucose metabolism and serum and tissue trehalase levels. As a first approach we used alloxan diabetic mice. The results obtained confirmed the existence of such a relation- -0 ship and warranted further experiments using the $\frac{5}{3}$ genetic diabetes models available in the C57 Black. mouse strain. Although quantitative differences were $\frac{0}{3}$ observed between the Swiss and C57 Black strains, both chemical and genetic models confirmed the $\frac{}{3}$ existence of such a relationship.

\section{Material and methods}

$\alpha, \alpha$-trehalose was purchased from Merck. Swiss $\tilde{O}$ albino mice, EOPS, were used as controls. Theyw were provided by Charles Rivers (Saint-Aubin les Elbeuf). Diabetes was induced in Swiss mice by ao single intravenous injection of alloxan monohydrate ( $90 \mathrm{mg} / \mathrm{kg}$ body weight). The animals were killed $3^{\stackrel{?}{+}}$ weeks after injection. Spontaneously diabetic animals 
were obtained from the Centre de Sélection et d'Elevage des Animaux de Laboratoire, CNRS (45045 Orléans Cedex). We used C57 B1/6 Orl/Ob mice, ${ }^{8}$ both homozygous $\mathrm{Ob} / \mathrm{Ob}$ and heterozygous $\mathrm{Ob} /+$, and $\mathrm{C} 57 \mathrm{Bl} \mathrm{Ks}$ Orl-Db mice, ${ }^{9}$ both homozygous $\mathrm{Db} / \mathrm{Db}$ and heterozygous $\mathrm{Db} / \mathrm{m}+$. As a control, we used C57 B1/6 mice. All the animals were exsanguinated through the orbital sinus.

Organs were excised, rinsed in cold saline, weighed, and homogenised in cold saline $(10 \mathrm{ml}$ final volume) for kidneys, and sodium bicarbonate/ calcium chloride $(1 \mathrm{~mol}, 0.5 \mathrm{~mol} \mathrm{v} / \mathrm{v}) 10 \mathrm{ml} / 1 \mathrm{~g}$ for liver, with Ultraturrax homogeniser-disintegrator (30 sX $\mathrm{X}^{2}$ at setting $20000 / \mathrm{min}$ ).

Trehalase activity was estimated in plasma as described previously on aliquots of $100 \mu 1 .^{10}$ One unit of enzyme ( $U$ Tr) was defined as the quantity of trehalase that hydrolyses $1 \mathrm{umol}$ substrate in one minute at $37^{\circ} \mathrm{C}$.

In each determination of trehalase activity, the conditions of steady state kinetics were respected and the activity was expressed as $\mathrm{U} \operatorname{Tr} / \mathrm{g}$ organ.

The computations were done on the logarithm, to the base 10 of 10 or 100 times the enzyme activity (units-units/g for organs). The data are thus normalised. The factor 10 or 100 avoided the introduction of negative logarithms. It has no effect on the variances.

\section{Results}

Trehalase activity in control and alloxan diabetic Swiss mice serum and organs expressed as log trehalase activity in units is shown in table 1. It can be seen that serum trehalase activity was significantly higher in the alloxan treated mouse serum than in the control mouse serum.

The liver trehalase activity appeared to be increased also, but the difference is not statistically significant because of the large variability of the results.

The kidney trehalase activity decreased slightly but significantly. The blood sugar was significantly increased in alloxan treated mice.

Table la shows the antilogarithms of the results calculated in table 1 .

Serum trehalase activity was $2 \cdot 19$ times higher in alloxan diabetic mice than in the controls and hepatic trehalase activity was 2.95 times higher, but there was a $12 \%$ decrease in renal trehalase activity. Blood sugar was 3.6 times higher in the alloxan diabetic mice serum as compared to the control serum. Glycosuria was increased in diabetic mice (250 times, results not shown).

Table 2 shows the serum, kidney, and liver trehalase activities for the heterozygous and homozygous diabetic mice strains derived from the original C57 B1/6 strain. In these strains the hyperglycaemic syndromes are considered to be related to single gene mutations. ${ }^{11}$ Serum trehalase activity was found to be increased in both heterozygous strains $(\mathrm{Ob} /+, \mathrm{Db} / \mathrm{m}+)$ compared to the original strain, although the difference on the logarithms is not significant for $\mathrm{Ob} /+$ and only slightly significant for $\mathrm{Db} / \mathrm{m}+$. Both homozygous strains exhibited an important and significant

TABLE 1 Serum, liver, and kidney trehalase activity of normal and alloxan diabetic Swiss mice. Enzyme activity is expressed as log 10 for serum $(10 \times$ units $/ \mathrm{ml})$ and kidney $(10 \times$ units $/ g$ organ $)$, and log 100 for liver $(100 \times$ units $/ g$ organ $)$. The numbers indicate the average values $(M)$, the standard deviation $(S D)$, and the standard error of the mean $(S E M)$. $t$ is calculated for $95 \%$ confidence limits.



NS, difference between control and alloxan treated groups not significant.

***, difference between control and alloxan treated groups significant $(p<0 \cdot 001)$.

TABLE 1a Geometric mean and factors corresponding to SD and SEM of serum, liver, and kidney trehalase activity in units, obtained by taking antilogarithms of results shown in table 1

\begin{tabular}{|c|c|c|c|c|c|c|c|c|c|c|c|c|}
\hline & \multicolumn{3}{|l|}{ Serum } & \multicolumn{3}{|l|}{ Liver } & \multicolumn{3}{|l|}{ Kidney } & \multicolumn{3}{|c|}{ Blood sugar } \\
\hline & $\begin{array}{l}\text { Geom } \\
\text { mean } \\
\text { (units) }\end{array}$ & $\begin{array}{l}S D \\
\text { factor }\end{array}$ & $\begin{array}{l}S E M \\
\text { factor }\end{array}$ & $\begin{array}{l}\text { Geom } \\
\text { mean } \\
\text { (units) }\end{array}$ & $\begin{array}{l}S D \\
\text { factor }\end{array}$ & $\begin{array}{l}S E M \\
\text { factor }\end{array}$ & $\begin{array}{l}\text { Geom } \\
\text { mean } \\
\text { (units) }\end{array}$ & $\begin{array}{l}S D \\
\text { factor }\end{array}$ & $\begin{array}{l}S E M \\
\text { factor }\end{array}$ & $\begin{array}{l}\text { Geom } \\
\text { mean } \\
\text { (units) }\end{array}$ & $\begin{array}{l}S D \\
\text { factor }\end{array}$ & $\begin{array}{l}S E M \\
\text { factor }\end{array}$ \\
\hline $\begin{array}{l}\text { Control mice } \\
\text { Alloxan treated mice }\end{array}$ & $\begin{array}{l}17 \cdot 7 \\
38 \cdot 9\end{array}$ & $\begin{array}{l}1 \cdot 48 \\
1 \cdot 41\end{array}$ & $\begin{array}{l}1 \cdot 09 \\
1 \cdot 08\end{array}$ & $\begin{array}{l}0 \cdot 251 \\
0 \cdot 741\end{array}$ & $\begin{array}{l}1 \cdot 18 \\
6 \cdot 91\end{array}$ & $\begin{array}{l}1 \cdot 74 \\
1 \cdot 55\end{array}$ & $\begin{array}{l}10 \cdot 6 \\
8 \cdot 31\end{array}$ & $\begin{array}{l}1 \cdot 12 \\
1 \cdot 2\end{array}$ & $\begin{array}{l}1 \cdot 03 \\
1 \cdot 04\end{array}$ & $\begin{array}{r}9 \cdot 815 \\
35 \cdot 075\end{array}$ & $\begin{array}{l}0 \cdot 845 \\
3 \cdot 541\end{array}$ & $\begin{array}{l}0 \cdot 189 \\
0 \cdot 223\end{array}$ \\
\hline
\end{tabular}


TABLE 2 Serum, liver, and kidney trehalase activity of homozygous and heterozygous mice strains exhibiting spontaneous diabetes as compared to the original mouse strain (C57 Bl/Orl). Enzyme activity is expressed as log 10 for serum $(10 \times$ units $/ \mathrm{ml})$ and kidney $(10 \times$ units $/ g$ organ $)$, and as $\log 100$ for liver $(100 \times$ units $/ g$ organ $)$. The numbers indicate the average values $(M)$, the standard deviation $(S D)$, and the standard error of the mean $(S E M) . t$ is calculated for $95 \%$ confidence limits.

\begin{tabular}{|c|c|c|c|c|c|c|c|c|c|c|c|c|c|}
\hline & \multirow[t]{2}{*}{ No } & \multicolumn{4}{|l|}{ Serum } & \multicolumn{4}{|l|}{ Liver } & \multicolumn{4}{|c|}{ Kidney } \\
\hline & & $M$ & $S D$ & $S E M$ & $t S E M$ & $M$ & $S D$ & $S E M$ & $t S E M$ & $M$ & $S D$ & $S E M$ & $t S E M$ \\
\hline $\begin{array}{l}\text { C57 Bl/orl } \\
\text { ob/t+ }\end{array}$ & $\begin{array}{l}10 \\
10\end{array}$ & $\begin{array}{l}1 \cdot 023 \\
1 \cdot 30 \\
\mathrm{NS}\end{array}$ & $\begin{array}{l}0.614 \\
0.018\end{array}$ & $\begin{array}{l}0.194 \\
0.008\end{array}$ & $\begin{array}{l}0.02 \\
0.03\end{array}$ & $\begin{array}{l}0.97 \\
1.09 \\
\text { NS }\end{array}$ & $\begin{array}{l}0.192 \\
0.195\end{array}$ & $\begin{array}{l}0.0607 \\
0.0617\end{array}$ & $\begin{array}{l}0 \cdot 12 \\
0 \cdot 18\end{array}$ & $\begin{array}{l}1.69 \\
1.62 \\
\text { NS }\end{array}$ & $\begin{array}{l}0.187 \\
0.0809\end{array}$ & $\begin{array}{l}0.059 \\
0.0255\end{array}$ & $\begin{array}{l}0.12 \\
0.04\end{array}$ \\
\hline$o b / o b$ & 10 & $\begin{array}{l}2.87 \\
* * *\end{array}$ & $0 \cdot 187$ & 0.0593 & $0 \cdot 14$ & 2.02 & 0.280 & 0.0886 & $0 \cdot 20$ & $\begin{array}{l}1 \cdot 64 \\
\text { NS }\end{array}$ & 0.094 & 0.0297 & 0.07 \\
\hline $\mathrm{db} / \mathrm{m}+$ & 16 & $\begin{array}{l}1.41 \\
*\end{array}$ & 0.225 & 0.062 & 0.13 & ${ }_{* *}^{1 \cdot 22}$ & $0 \cdot 186$ & 0.0589 & $0 \cdot 14$ & $\begin{array}{l}1 \cdot 80 \\
\text { NS }\end{array}$ & $0 \cdot 112$ & 0.028 & 0.06 \\
\hline $\mathrm{db} / \mathrm{db}$ & 16 & $\begin{array}{l}1 \cdot 99 \\
* * *\end{array}$ & 0.168 & 0.042 & 0.08 & $\begin{array}{l}2 \cdot 35 \\
* * * *\end{array}$ & 0.313 & 0.099 & $0 \cdot 23$ & $1 \cdot 87$ & 0.064 & 0.016 & 0.04 \\
\hline
\end{tabular}

Significance was calculated between the original strain and the heterozygotes and between the heterozygotes and homozygotes. Homozygous values differing significantly from heterozygous values also differ significantl; from those of the original strain.

NS, difference between control and spontaneous diabetic group not significant.

*, difference between control and spontaneous diabetic group significant $(p<0.05)$.

**, difference between control and spontaneous diabetic group significant $(p<0.01)$

$* * *$, difference between control and spontaneous diabetic group significant $(p<0.001)$.

TABLE 2a Geometric mean and factors corresponding to SD and SEM of serum, liver, and kidney trehalase activity in units, obtained by taking antilogarithms of results shown in table 2.



increase of serum trehalase activity compared to the corresponding heterozygous strains or to the original strain.

Liver trehalase activity was also increased slightly in $\mathrm{Ob} /+$ and significantly in $\mathrm{Db} / \mathrm{m}+$, as compared to the controls. A very big increase was noted again in both homozygous strains, compared to the corresponding heterozygous or the original strains.

The figure shows a histogram comparing the variations in blood serum and liver trehalase activity in the genetically and chemically diabetic mice. There is an apparent and good correlation between theincrease in serum and liver trehalase activity in the homozygous strains.

No important variation of trehalase activity could be found in the kidneys of homozygous and heterozygous strains.

The blood sugar level was significantly increased in both heterozygous strains. Glycosuria was slightly positive for $\mathrm{db} / \mathrm{m}+$ mice but was negative for $\mathrm{ob} /+$ mice.
Table 2a shows the antilogarithms of the results 윽 calculated in table 2 . In this case, there was an increase of serum trehalase activity of 1.9 times for $\mathrm{ob} /+, 70$ times for ob/ob, $2 \cdot 4$ times for $\mathrm{db} / \mathrm{m}+$, and $9 \cdot 3$ times for $\mathrm{db} / \mathrm{db}$.

For liver trehalase, the increase of activity was 1.3 times for ob/,+ 11 times for ob/ob, 1.8 times for $\mathrm{db} / \mathrm{m}+$, and 24 times for $\mathrm{db} / \mathrm{db}$. The renal trehalase activity showed only slight variation: an increase of 1.7 times for ob/,$+ 1 \cdot 12$ for ob/ob, and 0.77 and 0.66 times for $\mathrm{db} /+$ and $\mathrm{db} / \mathrm{db}$, respectively.

An analysis of variance of the above results was $\frac{D}{O}$ performed and the results are shown in table $3=$ comparing C57 B1, ob/t, ob/ob, db/m+, and $N$ $\mathrm{db} / \mathrm{db}$ mice using Scheffe's test. ${ }^{12}$ The results showed N a globally significant difference between sera, liver, N and glycaemia for the five mouse strains. In table 4 we list the comparison of the means according to Scheffe's test.

In order to explore the possible relationship between serum and liver trehalase activities and blood glucose levels, we compare in table 5 the 
TABLE 3 Analysis of variance of log 10 (10 $\times$ serum, $100 \times$ liver, $10 \times$ kidney) trehalase activity comparing C57 BI, $o b /+, o b / o b, d b / m+, d b / d b$.

\begin{tabular}{|c|c|c|c|c|c|}
\hline & & $D f$ & Sums of squares & Mean squares & Variance ratio \\
\hline Serum & $\begin{array}{l}\text { Between diabetic states } \\
\text { Residual } \\
\text { Total }\end{array}$ & $\begin{array}{r}4 \\
49 \\
53\end{array}$ & $\begin{array}{r}21 \cdot 229 \\
4 \cdot 758 \\
25 \cdot 987\end{array}$ & $\begin{array}{l}5 \cdot 307 \\
0 \cdot 0971\end{array}$ & $54 \cdot 65^{* * *}$ \\
\hline Liver & $\begin{array}{l}\text { Between diabetic states } \\
\text { Residual } \\
\text { Total }\end{array}$ & $\begin{array}{r}4 \\
45 \\
49\end{array}$ & $\begin{array}{r}15 \cdot 248 \\
2 \cdot 584 \\
17 \cdot 832\end{array}$ & $\begin{array}{l}3 \cdot 812 \\
0.0574\end{array}$ & $66 \cdot 41^{* * *}$ \\
\hline KiJnzy & $\begin{array}{l}\text { Between diabetic states } \\
\text { Residual } \\
\text { Total }\end{array}$ & $\begin{array}{r}4 \\
57 \\
61\end{array}$ & $\begin{array}{l}0 \cdot 6126 \\
0 \cdot 707 \\
1 \cdot 32\end{array}$ & $\begin{array}{l}0 \cdot 153 \\
0.0124\end{array}$ & $12 \cdot 33^{* * *}$ \\
\hline Glyca =m:ia & $\begin{array}{l}\text { Between diabetic states } \\
\text { Residual } \\
\text { Total }\end{array}$ & $\begin{array}{r}4 \\
40 \\
44\end{array}$ & $\begin{array}{l}2 \cdot 941 \\
0 \cdot 211 \\
3 \cdot 152\end{array}$ & $\begin{array}{l}0.735 \\
0.0052\end{array}$ & $141 \cdot 34^{* * *}$ \\
\hline
\end{tabular}
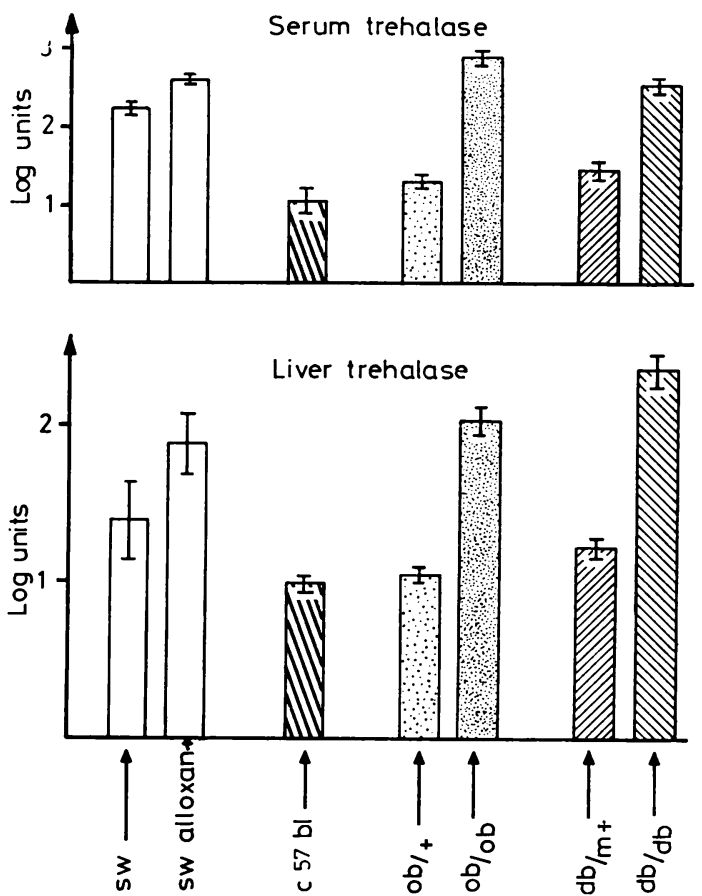

FIGURE Comparison of variations in blood serum and liver trehalase activities in the genetically and chemically diabetic mice.

percentage variation of these variables in the alloxan treated Swiss mice and in the heterozygous and the homozygous mutants of C57 Black.

It can be seen that there is no apparent relationship between the increase of serum and liver trehalase activities and the increase of blood glucose levels. The percentage increase of serum trehalase activity is of the same order in the alloxan treated animals as
TABLE 4 Scheffe's test for comparison of means.

\begin{tabular}{lllll}
\hline & \multicolumn{3}{l}{ Trehalase activity } & \\
\cline { 2 - 5 } & Serum & Liver & Kidney & Blood sugar \\
\hline Bl/ob+ & NS & NS & NS & $*$ \\
Bl/obob & $* * *$ & $* * *$ & NS & $* *$ \\
Bl/dbm & $* *$ & NS & $*$ & $* *$ \\
Bl/dbdb & $* * *$ & $* * *$ & $* *$ & $* * *$ \\
Ob+/obob & $* * *$ & $* * *$ & NS & NS \\
Ob+/dbm & NS & NS & $* *$ & NS \\
Ob+/dbdb & $* *$ & $* * *$ & $* * *$ & $*$ \\
dbm/dbdb & $* *$ & $* * *$ & NS & NS \\
dbm/obob & $* * *$ & $* * *$ & $* *$ & NS \\
Obob/dbdb & $* * *$ & $*$ & $* *$ & $*$ \\
\hline
\end{tabular}

TABLE 5 Relative increase of serum and liver trehalase and blood sugar levels expressed as percentage increase with respect to the control value.

\begin{tabular}{llll}
\hline & \multicolumn{2}{l}{$\Delta \%$ variation } \\
\cline { 2 - 4 } & $\begin{array}{l}\text { Serum } \\
\text { trehalase }\end{array}$ & $\begin{array}{l}\text { Liver } \\
\text { trehalase }\end{array}$ & $\begin{array}{c}\text { Blood } \\
\text { sugar }\end{array}$ \\
\hline Alloxan treated & & & \\
Swiss mice & 119 & 196 & 250 \\
ob/+ & 100 & 32 & 122 \\
ob/ob & 740 & 1015 & 205 \\
db/m+ & 144 & 78 & 189 \\
db/db & 765 & 2311 & 467 \\
\hline
\end{tabular}

in the heterozygous mutants and significantly lower than the percentage increase in the homozygotes.

Similar results were obtained for the liver trehalase activities. The relative increase after alloxan is a little higher than the one observed in the heterozygotes and much lower than the increase observed in the homozygotes.

On the other hand, the relative blood sugar increase is of the same order with alloxan as in the homozygous strains. These results indicate a lower insulin sensitivity of trehalase levels than of those enzymes involved in blood sugar regulation. 


\section{Discussion}

The comparison of trehalase activity in spontaneously diabetic mice and that in alloxan diabetic mice may be of value in the study of the mechanisms involved in the development of this metabolic disorder.

Since the work of Dunn et al, ${ }^{13-15}$ alloxan is known to destroy the $\beta$ cells of the islets of Langerhans thereby causing a lack of insulin. There is a morphological and functional involution of the pancreas and a progressive degranulation of the $\beta$ cells. ${ }^{16} 17$

The ob/ob mice show moderate spontaneous diabetes with moderate hyperglycaemia, hyperinsulinaemia, and a high gluconeogenic enzyme activity. They are markedly obese.

The $\mathrm{db} / \mathrm{db}$ mice show severe diabetes with higher hyperglycaemia than ob/ob mice, transitory hyperinsulinaemia, high gluconeogenic enzyme activity, and moderate obesity.

The heterozygous strains are apparently normal. ${ }^{18}$ We nevertheless found significant hyperglycaemia compared with C57 B1/6 strain.

Both mouse strains carry autosomal mutations at either the diabetes $(\mathrm{db})$ or the obesity (ob) loci. The $\mathrm{db}$ locus is on chromosome 4 , linkage group VIII, and the ob mutation is on chromosome 6 , linkage group XI.

Chick et al ${ }^{19}$ showed abnormalities in glucose tolerance primarily restricted to male heterozygous mice $(\mathrm{db} / \mathrm{m}+)$. In this context it should be mentioned that we noticed a significant difference between the fasting blood glucose levels and the serum trehalase activity of normal male and female C57 B1/Orl mice.

It is interesting to note that serum and liver trehalase activities increased very strongly in both homozygous diabetic strains. This increase was much more pronounced than the one produced by alloxan treatment. The heterozygous strains $(\mathrm{ob} /+$, $\mathrm{db} / \mathrm{m}+$ ) showed only a moderate or no increase of serum or liver trehalase levels. No variation of kidney trehalase activity could be found either with alloxan or in the genetically diabetic strains. These results are in agreement with our former proposition concerning the possible hepatic origin of the serum enzyme trehalase. ${ }^{20}$

No direct correlation could be found between serum and liver trehalase activities and blood sugar levels. The largest increase in blood sugar (approximately 3.5 times) was seen in the alloxan treated animals. Furthermore, a large increase in blood sugar was found in the heterozygous (ob/+, $\mathrm{db} / \mathrm{m}+$ ) strains with moderate or no increase of liver trehalase activity. These results are in agree-

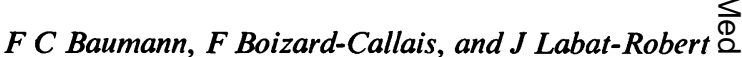

ment with the highly improbable idea that trehalase $\frac{\mathcal{D}}{\overparen{D}}$ is involved in the regulation of blood glucose levels. $\stackrel{\mathbb{P}}{?}$

However, trehalase in liver and serum may well $\vec{\Rightarrow}$ be the result of the 'survival' of a gene, probably in close association with other genes, coding for enzymes involved in the regulation of glucose metabolism. $\frac{O}{\bar{D}}$ In this case a correlation might be expected between $\frac{\vec{\sigma}}{\vec{\sigma}}$ the expression of these genes and the one coding for $\propto$ trehalase, both being sensitive to the same hormonal of and genetic regulatory mechanisms.

The increase of the liver trehalase activity may thus be related to the previously noted increase of $\vec{\omega}$ the liver enzymes involved in gluconeogenesis in the same homozygous strains. ${ }^{21} 22$ The lack of difference in $\mathrm{Ob} /+$ mice and the slight increase in $\mathrm{Db} / \mathrm{m}+\dot{\vec{\phi}}$ mice, as compared to the very large increase in the $\stackrel{\infty}{o}$ homozygous mice, suggests the possibility of a $\vec{A}$ repression mediated mechanism. Such a repression $\vec{\infty}$ mechanism could depend on the synthesis of a 은 substance coded for by the modified genes. The presence of one set of normal genes out of two could be nearly enough to ensure the synthesis of an $\varnothing_{\varnothing}$ adequate amount of the repressor substance. In the $\frac{\Phi}{3}$ absence of both sets of normal genes it could be $\underset{\mathbb{D}}{ }$ synthesised, leading to the full expression of the structural genes coding for trehalase.

The gene(s) coding for trehalase may be part of set of structural genes for glucose metabolising. enzyme, which evolved together from bacteria te insects where trehalose is the major circulating carbohydrate. The trehalase gene could have remained in association with the other genes of $\stackrel{\square}{\propto}$ glucose metabolising enzymes without playing any $\overrightarrow{\vec{F}}$ further role in intermediary metabolism of verte- $\frac{9}{3}$ brates. It would then react to the same stimuli as the other enzymes and its activity would co-vary with those of other glucose metabolising enzymes. The regulatory influence of insulin or insulin dependent mechanisms or both would then be $\dot{0}$ expected to play a role in the regulation of the 3 . expression of the trehalase gene, which has been 8 localised on chromosome 14. The fact that the 3 homozygous $\mathrm{Ob} / \mathrm{Ob}$ and $\mathrm{Db} / \mathrm{Db}$ strains show a $\mathrm{O}$ much higher increase of liver trehalase than the alloxan treated mice (compared to their respective $\frac{T}{0}$ controls) is in favour of a genetically determined regulatory mechanism.

Although this mechanism is compatible with our $N$ results, it remains entirely speculative and other N explanations can also be offered. It should be $\sigma$ remembered also that several different biosynthetic pathways appear to be disturbed in the genetic diabetic mouse strains, for instance, the regulation $\stackrel{\oplus}{\rightleftharpoons}$ of the relative rates of synthesis of type I and type III 0 collagens. ${ }^{23}$ These considerations, as well as the 
sex and strain differences in serum and liver trehalase activity (Baumann and Labat-Robert, unpublished work, and tables 1 and 2), suggest complex regulatory mechanisms for trehalase activity, one of which appears to be closely related to those involved in the metabolic determination of diabetes.

\section{References}

1 Elbein AD. The metabolism of $\alpha, \alpha$-trehalose. In: Tipson RS, Horton D, eds. Advances in carbohydrate chemistry. Vol 30. New York: Academic Press, 1974:227-56.

2 Sacktor B. Trehalase and the transport of glucose in mammalian kidney and intestine. Proc Natl Acad Sci USA 1968;60:1007-14.

3 Sacktor B, Berger SJ. Formation of trehalose from glucose in the renal cortex. Biochem Biophys Res Comm 1969;35: 796-800.

4 Bergoz R. Trehalose-malabsorption causing intolerance to mushroom. Gastroenterology 1971;60:909-12.

5 Demelier JF, Bark C, Labat J, Courtois JE. Activités tréhalasiques du sérum et de l'urine chez l'homme. In: Clinical enzymology. Vol 2. 7th Int Congr Clin Chem. Basel: Karger, 1970:187-94.

6 Eze LC, Price-Evans DA. Plasma trehalase activity in diabetes mellitus. Clin Chim Acta 1970;28:153-9.

7 Courtois JE, Demelier JF. Répartition de la tréhalase chez l'homme et quelques mammifères. Bull Soc Chim Biol 1966;48:277-86.

8 Coleman DL, Hummel KP. The influence of genetic background on the expression of the obese (ob) gene in the mouse. Diabetologia 1973;9:287-93.

9 Chick WL, Like AA. Studies in the diabetic mutant mouse. IV DBM, a modified diabetic mutant produced by outcrossing of the original strain. Diabetologia 1970;6: 252-6.

10 Bark C. Contribution à l'étude de la tréhalase sérique et urinaire de l'homme. Thèse Doct Etat Pharm. Paris. 1974.

11 Camerini-Davalos RA, Redde AS, Velasco CA, Oppermann W, Wehner H, Bloodworth JMB. Microangiopathy in genetic prediabetes. In: Robert AM, Boniface R, Robert L, eds. Frontiers of matrix biology. Vol 7. Basel: Karger, 1979:281-95.
12 Scheffe $\mathbf{H}$. A method for judging all contrasts in the analysis of variance. Biometrica $1953 ; 40,87-104$.

13 Dunn SJ, Kirkpatrick J, McLetchie NG, Telfer S. Necrosis of the islets of Langerhans produced experimentally. J Pathol Bact 1943;55:245-57.

14 Dunn SJ, McLetchie NG. Experimental alloxan diabetes in the rat. Lancet 1943 ; iii:384-7.

15 Dunn SJ, Sheehan HL, McLetchie NG. Necrosis of islets of Langerhans produced experimentally. Lancet $1943 ; \mathbf{i}$ : 484-7.

16 Bunnag SG, Warner NE, Bunnag S. Effect of alloxan on the mouse pancreas during and after recovery from diabetes. Diabetes 1967;16:83-9.

17 Boizard F, Huyen LVN, Quevauviller A. Aspect histologique de quelques organes d'un modèle de diabète alloxanique chez la souris. CR Soc Biol (Paris) 1980;173: 712-8.

18 Stauffacher W, Orci L, Amherdt M, Lambert AM, Renold AE, Rouiller C. Le diabète spontané chez l'animal. Considérations sur la pathogénèse du syndrome aigu et sur la morphologie des lésions du syndrome chronique. Path Biol 1970;18:539-49.

19 Chick WL, Lavine RL, Like AA. Studies in the diabetic mutant mouse. $V$ Glucose tolerance in mice homozygous and heterozygous for the diabetes $(\mathrm{db})$ gene. Diabetologia $1970 ; 6: 257-62$.

20 Demelier JF, Massari M, Courtois JE, Labat J. Tréhalase du sérum humain dans quelques affections hépatiques. Clin Chim Acta 1971;35:335-43.

21 Chang AY, Schneider DI. Abnormalities in hepatic enzyme activities during development of diabetes in $\mathrm{db}$ mice. Diabetologia 1970;6:274-8.

22 Seidman I, Horland AA, Teebor GW. Glycolytic and gluconeogenic enzyme activities in the hereditary obese hyperglycemic syndrome and in acquired obesity. Diabetologia 1970;6:313-6.

23 Kern P, Moczar M, Robert L. Biosynthesis of skin collagens in normal and diabetic mice. Biochem J 1979; $182: 337-45$.

Requests for reprints to $\mathrm{Dr} \mathbf{J}$ Labat-Robert, Laboratoire de Biochimie du Tissu Conjonctif, Faculté de Médecine, 8 rue du Général Sarrail, 94010 Créteil, France. 